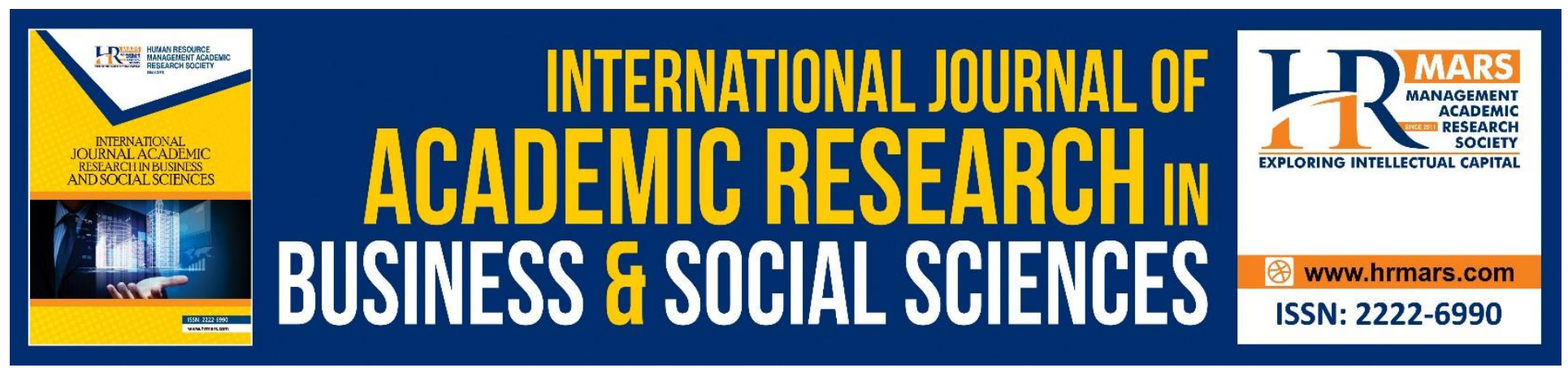

\title{
Exploring and Developing an Instrument for Measuring System Quality Construct in The Context of E-Learning
}

Maha Ismail Alkhawaja, Mutia Sobihah, Zainuddin Awang

To Link this Article: http://dx.doi.org/10.6007/IJARBSS/v10-i11/7953

DOI:10.6007/IJARBSS/v10-i11/7953

Received: 09 September 2020, Revised: 30 September 2020, Accepted: 21 October 2020

Published Online: 19 November 2020

In-Text Citation: (Alkhawaja, Sobihah, \& Awang, 2020)

To Cite this Article: Alkhawaja, M. I., Sobihah, M., \& Awang, Z. (2020). Exploring and Developing an Instrument for Measuring System Quality Construct in The Context of E-Learning. International Journal of Academic Research in Business and Social Sciences. 10(11), 403-413.

Copyright: (c) 2020 The Author(s)

Published by Human Resource Management Academic Research Society (www.hrmars.com)

This article is published under the Creative Commons Attribution (CC BY 4.0) license. Anyone may reproduce, distribute, translate and create derivative works of this article (for both commercial and non-commercial purposes), subject to full attribution to the original publication and authors. The full terms of this license may be seen

at: http://creativecommons.org/licences/by/4.0/legalcode

Vol. 10, No. 11, 2020, Pg. 403 - 413

http://hrmars.com/index.php/pages/detail/IJARBSS

JOURNAL HOMEPAGE

Full Terms \& Conditions of access and use can be found at http://hrmars.com/index.php/pages/detail/publication-ethics 


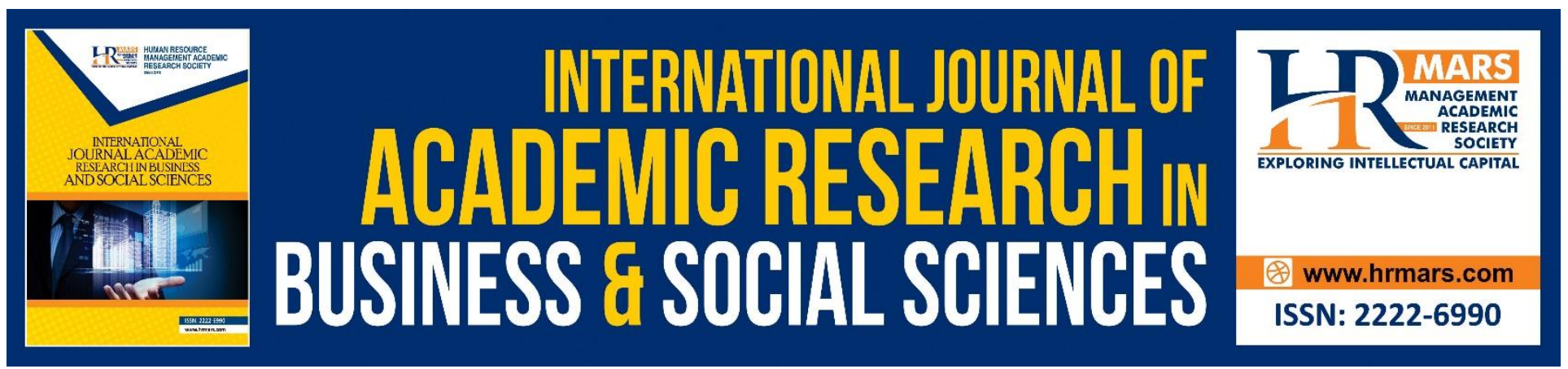

\title{
Exploring and Developing an Instrument for Measuring System Quality Construct in The Context of E-Learning
}

\author{
Maha Ismail Alkhawaja, Assoc. Prof. Dr. Mutia Sobihah, Prof. \\ Zainuddin Awang
}

Faculty of Business and Management, University Sultan Zainal Abidin, 21300 Kuala Terengganu, Malaysia

Email: memkhawajah@yahoo.com, mutiasubihah@unisza.edu.my zainudinawang@unisza.edu.my

\begin{abstract}
In this study, an instrument for measuring system quality was examined for analyzing the acceptance of the e-learning system in higher education in Jordan. This study thereby obtained twenty-four system quality items from prior studies and different industries, and these were modified according to the e-learning industry. The items were validated by experts, and a pilot study was then executed with 150 randomly chosen students from three Jordanian public universities as participants for this study. Five dimensions (i.e., adaptability, availability, reliability, response time, and usability) were created using the Exploratory Factor Analysis (EFA), and internal reliability was achieved for the five dimensions.
\end{abstract}

Keywords: E-Learning System, System Quality, Instrument, Measurement.

\section{Perpose of the Study}

The main objective of this study:

- To inspect a multidimensional instrument employed in measuring the items related to the system quality construct in context of e-learning system in higher education.

The instrument items were obtained from prior literature and modified to ensure they fit with the purpose of this study. As per the suggestions of Awang (2016), the content validity, criterion validity, and face validity of the instrument were examined. Further, the exploratory factor analysis (EFA) test was implemented to verify its validity and reliability.

\section{Background}

Various e-learning structures are available at present. However, it has been challenging to develop a successful e-learning environment. In fact, issues related to the quality of e-learning in the context of higher education in Jordan have become a serious concern. As highlighted by Arkorful (2015), the 
quality issues and challenges need to be extensively examined from the viewpoints of learners. Furthermore, effective solutions need to be established to increase the involvement of students.

E-learning has been utilized as a static learning method by the majority of universities in Jordan. Aladwan et al. (2018) reported that the e-learning process in most Jordanian universities involves the use of standardized online materials; students log in to the e-learning system to access studying materials and interact with their teachers. The literature review makes it clear that there are system quality issues that directly affect the students' behaviors toward the system, and several studies have been carried out with the aim to improve the quality of the e-learning system (Pham, Williamson, \& Berry, 2018; Alkhawaja \& Halim, 2019).

Delone and Mclean (2003) described system quality as the level to which the utilization of a given system is effortless. Accordingly, upon measuring the preferred features of a system, DeLone and McLean (2013) presented five attributes of system quality, namely availability, usability, adaptability, response time, and reliability. Further, Calisir et al, (2015) identified system quality as a key factor for the formation of an effective e-learning system that students can benefit from. Jaber (2016) illustrated that students that have positive attitudes toward the system and advised by their friends to use the system would change their behavior towards the system if they simply lack access to the system and students are expected to be competent in accessing the system at any time and location as well as have the ability to effectively and efficiently use the system. They should be able to quickly download items and perform transactions on the system pages to attain the optimum level of benefits offered by e-learning.

\section{Methodology}

Public universities were considered over private universities for this study due to the fact that private universities have better infrastructure and receive funds of private institutions which leaves the public universities with in a weaker situation regarding the e-learning system sophistication. Three Jordanian public universities that represent three regions of the country were randomly chosen. The northern region was represented by Al Yarmouk University, the central region was represented by Al Balqa University, while the southern region was represented by Mua'ta University.

For the EFA, Spielberger and Gorsuch (1983) proposed using a minimum of 100 samples to obtain valid results. For the present study, questionnaires were distributed to a total of 150 students, who were chosen randomly. These students were excluded from the final sample. The questionnaires were randomly distributed and collected. A total of 120 questionnaires were valid to be analyzed.

\section{Instrument}

The 24 items included in the questionnaire were equipped with a 10-point interval scale. As explained by Hoque et al. (2017a) and Hoque and Awang (2016b), the 10-point interval scale presents the respondents with more response options that correspond with their specific judgment of a question. The score of 1 denotes "strongly disagree," whereas the score of 10 denotes "strongly agree." The items in the instrument were adapted from past studies. The respondents were also asked to provide demographic details such as age group, gender, university name, current year of education and years of internet experience through the questionnaire.

The items in the questionnaire were comprehensively evaluated for reliability and validity, and for this purpose, experts in the field were sought. As described by Cooper and Schindler (2003), reliability is the degree to which a measure is not afflicted by random errors, and a reliable instrument provides 
INTERNATIONAL JOURNAL OF ACADEMIC RESEARCH IN BUSINESS AND SOCIAL SCIENCES Vol. 10, No. 11, 2020, E-ISSN: 2222-6990 @ 2020 HRMARS

consistent results, whereas validity is the extent to which a score truly denotes a concept. It can, therefore, be described as the accurateness of the measurement method and indicates the scale's capacity to measure what it should (Cooper \& Emory, 1994; Zikmund, 2000). Face validity, content validity, and criterion validity are the three forms of validity evaluation. Specifically, face validity is the degree to which a measure denotes the content of a given concept. Directly linked to face validity, content validity relates to whether a measure includes a descriptive set of items to represent a given concept. As for criterion validity, Zikmund (2000) described it as the correlation level of a measure with other ordinary measures for an exact construct. The instrument's items were evaluated by experts, including associate doctors and professors in social sciences and e-learning.

\section{The Exploratory Factor Analysis (EFA) Procedure}

The revised questionnaire was distributed to the 150 randomly chosen respondents for the purpose of collecting data for the pilot study. The EFA was employed using the collected data to discover and measure the dimensionality of the items measuring the construct. Many researchers, such as Awang (2010, 2012), Hoque et al. (2017, 2018), and Yahaya et al. (2018), have stressed that EFA should be employed for every construct to determine if the items will create different dimensions of previous studies. The dimensionality of the items may change if items are adapted from different fields to a new field of study. Furthermore, differences in the cultural background and socio-economic status of the population as well as the lapse in time (duration) between the present and earlier studies may also change the dimensionality. In other words, it is expected that the current study will produce new dimensions, especially that the present study is conducted in a new environment (Awang, 2010, 2012; Hoque et al., 2018).

\section{EfA for the construct System Quality}

In the questionnaire for this study, the construct system quality was represented by 24 items. Accordingly, Table 1 show the descriptive statistics for every item measuring the construct. The interval scale from 1 (strongly disagree) to 10 (strongly agree) was employed to give a wide range of options as recommended by (Awang et al., 2016; Hoque et al., 2018; Bahkia et al., 2019). Standard deviation was calculated to understand the data distribution. Standard deviation defines the normal distribution of the data based on the error and variance values to identify the mean. Table 1 shows the mean and standard deviation cuts for each item.

Table 1: The mean and standard deviation for items measuring System Quality Construct

\begin{tabular}{llcc}
\hline \multicolumn{1}{c}{ Item Statement } & \multicolumn{2}{c}{$\begin{array}{c}\text { Std. } \\
\text { Deviation }\end{array}$} \\
\hline SQ1 & $\begin{array}{l}\text { It is easy to communicate with my teacher through the e-learning } \\
\text { system. }\end{array}$ & 9.46 & .709 \\
SQ2 & $\begin{array}{l}\text { It is easy to communicate with other students through the e- } \\
\text { learning system. }\end{array}$ & 9.26 & .680 \\
SQ3 & The e-learning system allows to download files. & 9.43 & .683 \\
SQ4 & The e-learning system allows to upload files. & 9.28 & .724 \\
SQ5 & The e-learning system is flexible in addressing needs. & 9.43 & .683 \\
SQ6 & The e-learning system can be adapted to meet variety of tasks. & 9.27 & .733 \\
SQ7 & The e-learning system can be used anywhere & 9.43 & .682 \\
\hline
\end{tabular}


INTERNATIONAL JOURNAL OF ACADEMIC RESEARCH IN BUSINESS AND SOCIAL SCIENCES Vol. 10, No. 11, 2020, E-ISSN: 2222-6990 @ 2020 HRMARS

\begin{tabular}{llll}
\hline SQ8 & The e-learning system is available at any time of the day. & 8.92 & .842 \\
SQ9 & The e-learning system allows me to access the needed information & 8.84 & .789 \\
& whenever I need to. & \\
SQ10 & The e-learning system make Information more easy to access. & 8.83 & .967 \\
SQ11 & The e-learning system is always available. & 9.10 & .771 \\
SQ12 & Course materials are quickly accessible through the e-learning & 8.83 & .984 \\
& system. & & \\
SQ13 & The e-learning system content loads quickly. & 8.58 & .958 \\
SQ14 & The e-learning system enables quick interactive communication. & 8.50 & .879 \\
SQ15 & The response time of the e-learning system is consistent. & 8.62 & .900 \\
SQ16 & The e-learning system is reliable. & 8.77 & .974 \\
SQ17 & The operation of the e-learning system is dependable. & 8.61 & .823 \\
SQ18 & The e-learning system consistently provides good services. & 8.85 & .847 \\
SQ19 & The e-learning system operates sufficient features. & 9.00 & .944 \\
SQ20 & It is easy to navigate the e-learning system. & 8.91 & .879 \\
SQ21 & The e-learning system is user-friendly. & 8.97 & .798 \\
SQ22 & The size and resolution of the e-learning system interface is good. & 9.05 & .818 \\
SQ23 & The e-learning system's functions are considered to be satisfied. & 9.01 & .783 \\
SQ24 & It is easy to navigate the e-learning system. & 9.17 & .771 \\
\hline
\end{tabular}

As indicated by the results in Table 2, Bartletts' test of sphericity was significant ( $p$-value $<0.05$ ). Furthermore, the Kaiser-Meyer-Olkin (KMO) measuring the adequacy of sampling has exceeded the required value of 0.6 (Awang, 2010, 2012; Hoque et al., 2018; Bahkia et al., 2019). Accordingly, the achieved results of the two tests (Bartlett's test significance and $\mathrm{KMO}>0.6$ ) indicate that the data is adequate for data reduction procedure.

Table 2: The KMO and Bartlett's Test Score

\begin{tabular}{lcl}
\hline KMO and Bartlett's Test & & \\
\hline $\begin{array}{l}\text { Kaiser-Meyer-Olkin } \\
\text { Adequacy. Measure of Sampling }\end{array}$ & & \\
Bartlett's Test & of Approx. Chi-Square & 1710.815 \\
Sphericity & Df & 276 \\
& Sig. & .000 \\
\hline
\end{tabular}

Figure 1 specifies the components that emerged from the scree plot in EFA procedure. This procedure resulted in grouping the 24 items into five components. Each component represents a set of measuring items. According to (Awang, 2010, 2012; Hoque et al., 2018), The rotated component matrix will specify which item belong to which component. 
INTERNATIONAL JOURNAL OF ACADEMIC RESEARCH IN BUSINESS AND SOCIAL SCIENCES Vol. 10, No. 11, 2020, E-ISSN: 2222-6990 @ 2020 HRMARS

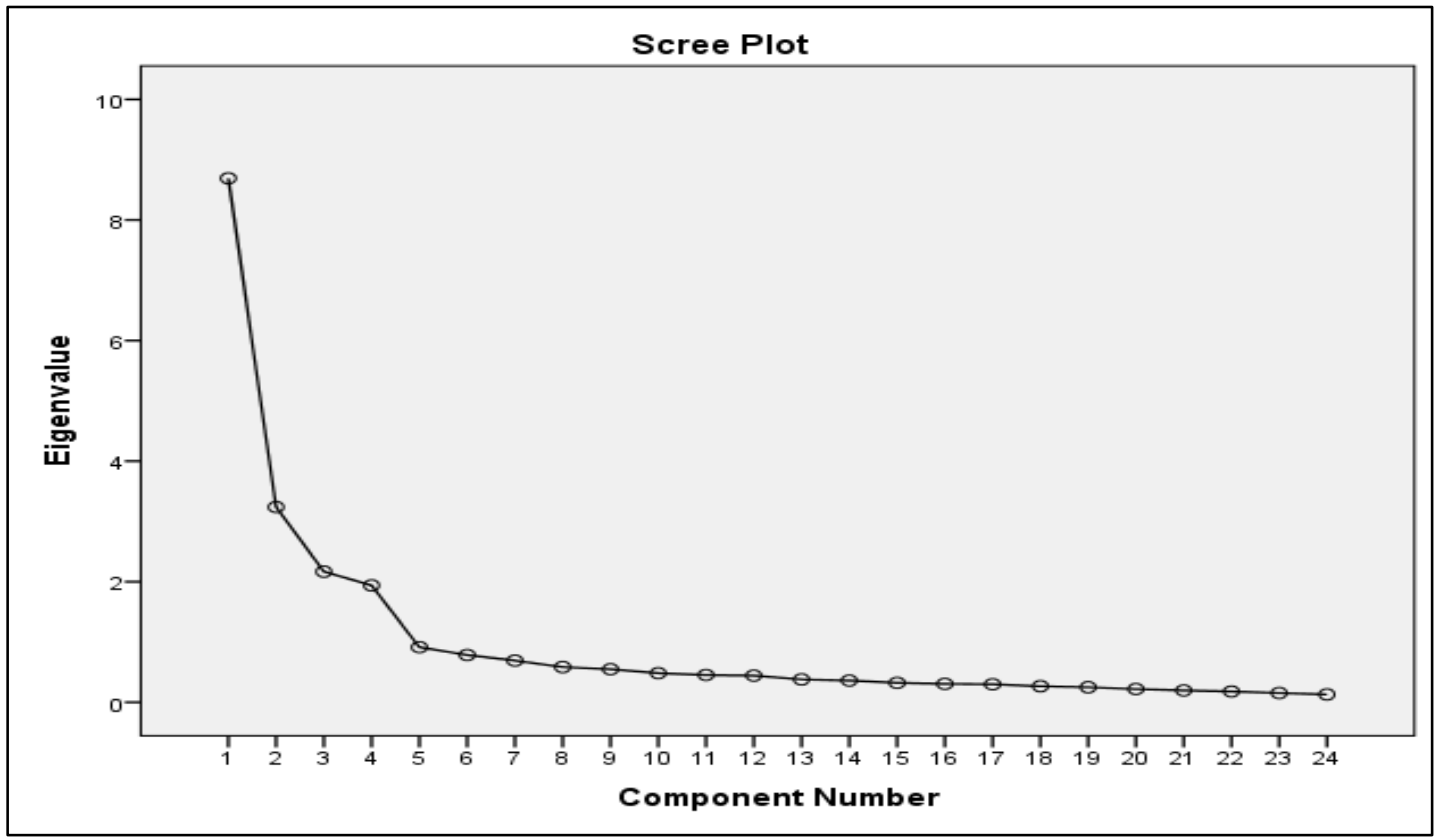

Figure 1: The Scree Plot shows five components emerged from the EFA procedure

\section{Dimensions and Total Variance}

Results given in Table 3 show the five components that are greater than 1.0 that emerged from computing eigenvalue. The values extended between 1.352 and 8.7.688. Meanwhile, the explained variance for the first component was $32.0325 \%, 46.804 \%$ for the second, $56.014 \%$ for the third, $63.871 \%$ for the fourth, and $69.503 \%$ for the fifth. The total explained variance upon measuring this construct was $69.503 \%$, which was acceptable, as it exceeded the least possible requirement of $60 \%$ (Awang, 2010, 2012; Hoque et al., 2017, 2018; Yahaya et al., 2018 and Bahkia et al., 2019).

Table 3: The Total Variance Explained for the Construct

\begin{tabular}{|c|c|c|c|c|c|c|}
\hline \multicolumn{7}{|c|}{ Total Variance Explained } \\
\hline \multirow{3}{*}{$\begin{array}{l}\text { Compon } \\
\text { ent }\end{array}$} & \multicolumn{3}{|c|}{$\begin{array}{l}\text { Extraction Su } \\
\text { Loadings }\end{array}$} & \multicolumn{3}{|c|}{ Rotation Sums of Squared Loadings } \\
\hline & \multicolumn{3}{|r|}{ of Cumulative } & \multicolumn{3}{|c|}{$\% \quad$ of } \\
\hline & Total & Variance & $\%$ & Total & Variance & Cumulative $\%$ \\
\hline 1 & 7.688 & 32.032 & 32.032 & 7.688 & 32.032 & 32.032 \\
\hline 2 & 3.545 & 14.772 & 46.804 & 3.545 & 14.772 & 46.804 \\
\hline 3 & 2.211 & 9.211 & 56.014 & 2.211 & 9.211 & 56.014 \\
\hline 4 & 1.886 & 7.857 & 63.871 & 1.886 & 7.857 & 63.871 \\
\hline 5 & 1.352 & 5.632 & 69.503 & 1.352 & 5.632 & 69.503 \\
\hline Extractior & netho & Principal & Component An & ysis. & & \\
\hline
\end{tabular}

The extraction method of Principal Component Analysis (PCA) with VariMax (Variation Maximization) rotation was implemented on the 24 items. The five components and their respective items that were obtained from the EFA procedure are presented in Table 4. The required factor loading for an item to be retained should be greater than 0.6 , items with lower factor loadings would be deleted (Awang, 
INTERNATIONAL JOURNAL OF ACADEMIC RESEARCH IN BUSINESS AND SOCIAL SCIENCES Vol. 10, No. 11, 2020, E-ISSN: 2222-6990 @ 2020 HRMARS

2010, 2012; Yahaya et al., 2018; Bahkia et al., 2019). However, as Table 4 shows, all the factor loadings for the rotated items are greater than 0.6 .

Table 4: The components and their respective items Rotated Component Matrix ${ }^{a}$ Component

\begin{tabular}{lllll}
\hline 1 & 2 & 3 & 4 & 5
\end{tabular}

ADA1 .855

ADA2 .798

ADA3 $\quad .838$

ADA4 .755

ADA5 .794

ADA6 .789

AVA1 $\quad .680$

AVA2 $\quad .768$

AVA3 $\quad .778$

AVA4 $\quad .744$

AVA5 $\quad .797$

RST1

.726

RST2

.812

RST3

.785

RST4

.782

REL1 $\quad .684$

REL2 $\quad .762$

REL3 $\quad .810$

REL4 $\quad .786$

USA1 $\quad .741$

USA2 $\quad .705$

USA3 $\quad .788$

USA4 $\quad .813$

USA5 $\quad .774$

Extraction Method: Principal Component Analysis.

a. Rotation converged in 6 iterations.

The combined items performed five components. Namely, Adaptability, Availability, Response time, Reliability and Usability. The 24 items were retained due to high factor loading (>0.6).

\section{The Instrument Internal Reliability}

Finally, the internal reliability of the retained items was computed through the Cronbach's alpha value. The internal reliability specifies the effectiveness level of a particular set of items in measuring the respective construct. The threshold value of Cronbach's alpha for the items to achieve internal reliability is greater than 0.7 (Awang, 2010, 2012). Table 5 presents the Cronbach alpha score for each component. 
INTERNATIONAL JOURNAL OF ACADEMIC RESEARCH IN BUSINESS AND SOCIAL SCIENCES Vol. 10, No. 11, 2020, E-ISSN: 2222-6990 @ 2020 HRMARS

Table 5: The Internal Reliability for the Construct

\begin{tabular}{lll}
\hline Component & N of Items & Cronbach's Alpha \\
\hline Adaptability & 6 & 0.914 \\
Availability & 5 & 0.844 \\
Reliability & 4 & 0.854 \\
Response Time & 4 & 0.875 \\
Usability & 5 & 0.849 \\
All items & $\mathbf{2 4}$ & $\mathbf{0 . 9 0 4}$ \\
\hline
\end{tabular}

The items were all found to be internally reliable, as their Cronbach's alpha scores exceeded 0.7.

\section{Conclusion}

The present study contributes to the measurement of the system quality construct, particularly in the context of e-learning field in Jordanian universities. five dimensions of system quality were extracted: adaptability, availability, reliability, response time, and usability. Further, these dimensions were measured using 24 items, and the reliability measures for the five dimensions/components of system quality resulted in high Cronbach's alpha values, thereby meeting the Bartlett test requirements (significant), satisfactory KMO scores (>0.6) and factor loadings that exceeded the minimum value of 0.6. The obtained results showed that the considered items were applicable for this study. The severe scale improvement and validation measures for this study ensure that the novel system-quality instrument is internally consistent and stable crosswise the sample.

\section{Contribution}

This study contributes to the field of e-learning system by evaluating and testing items that fit for testing the construct system quality in context of e-learning system. a novel survey was developed and validated. this instrument is a methodological contribution for the field. Items were adapted from diverse fields and modified to fit the field of e-learning system. The instrument has been validated through face validation, content validity and reliability.

Researchers in the field of e-learning system can use this survey in different locations and different levels of population.

\section{Recommendations}

This instrument is recommended to be used among the information system field, specially e-learning system. Additionally, it is recommended for future studies in the field of e-learning to measure different items and more questions that can explain different components of the construct system quality. Moreover, the output of this investigation can be expanded by implementing this instrument in different fields of knowledge and test in in additional populations and diverse industries. As this study targeted students of public universities, it is recommended to adopt this instrument and investigate the outcome in private universities in Jordan or even to use it in different countries. Another recommendation for future work is to utilize a different analysis tools to analyze the instrument of this study and compare the output.

\section{References}

Agrawal, V., Agarwal, S., \& Agrawal, A. M. (2017). Perception of employees toward e-learning service 
INTERNATIONAL JOURNAL OF ACADEMIC RESEARCH IN BUSINESS AND SOCIAL SCIENCES

Vol. 10, No. 11, 2020, E-ISSN: 2222-6990 @ 2020 HRMARS

quality: exploratory factor analysis. Industrial and Commercial Training, 49(7/8), 350-356. https://doi.org/10.1108/ICT-06-2017-0042

Aladwan, F., Fakhouri, H. N., Alawamrah, A., \& Rababah, O. (2018). Students Attitudes toward Blended Learning among students of the University of Jordan. Modern Applied Science, 12(12), 217. https://doi.org/10.5539/mas.v12n12p217

Al-Debei, M. M., Akroush, M. N., \& Ashouri, M. I. (2015). Consumer attitudes towards online shopping. Internet Research, 25(5), 707-733. https://doi.org/10.1108/IntR-05-2014-0146

Alkhawaja, M. I., \& Halim, M. S. B. A. (2019). Challenges of E-Learning System Adoption in Jordan Higher Education. International Journal of Academic Research in Business and Social Sciences, 9(9), 487-494.

Arkorful, V., \& Abaidoo, N. (2015). The role of e-learning, advantages and disadvantages of its adoption in higher education. International Journal of Instructional Technology and Distance Learning, 12(1), 29-42.

Awang, Z. (2010). Research Methodology for Business and Social Sciences. Universiti Teknologi MARA. Malaysia

Awang, Z. (2012). Research methodology and data analysis. Penerbit Universiti Teknologi MARA Press. Malaysia.

Awang, Z. (2014). A handbook on SEM for academicians and practitioners: the step by step practical guides for the beginners. Bandar Baru Bangi, MPWS Rich Resources.

Awang, Z. (2015). SEM Made Simple: A Gentle Approach to Learning Structural Equation Modelling. Bandar Baru Bangi, MPWS Rich Resources.

Awang, Z., Afthanorhan, A., \& Mamat, M. (2016). The Likert scale analysis using parametric based Structural Equation Modeling (SEM). Computational Methods in Social Sciences, 4(1), 13-21.

Bahkia, A.S., Awang, Z., Afthanorhan, A., Ghazali, P.L., Foziah, H. (2019). Exploratory Factor Analysis on occupational stress in context of Malaysian sewerage operations AIP Conference Proceedings.

Calisir, F., Gumussoy, C. A., Bayraktaroglu, A. E., \& Karaali, D. (2015). Predicting the Intention to Use a Web-Based Learning System : Perceived Content Quality, Anxiety, Perceived System Quality , Image , and the Technology Acceptance Model, 24(5), 515-531. https://doi.org/10.1002/hfm Cooper, D. R., \& Emory, C. W. (1994). Business Research Methods, Brooks.

Cooper, D. R., \& Schindler, P. S. (2003). Business Research Methods McGraw-Hill: New York.

DeLone, W. H., \& McLean. (2013). The DeLone and McLean Model of Information Systems Success : A Ten-Year Update. Journal of Management Information Systems, 8(4), 9-30. https://doi.org/10.1073/pnas.0914199107

Delone, W. H., \& Mclean, E. R. (2003). Journal of Management The DeLone and McLean Model of Information Systems Success: A Ten-Year Update, (March 2015), 37-41. https://doi.org/10.1080/07421222.2003.11045748

Hoque, A. S. M. M., \& Awang, Z. (2016). The Sway of Entrepreneurial Marketing on Firm Performance: Case of Small and Medium Enterprises (SMEs) in Bangladesh. In Terengganu International Business and Economics Conference (TiBEC-V), Terengganu, Universiti Teknologi Mara (UiTM) (pp. 174-194).

Hoque, A.S.M.M, Awang, Z., Jusoff, K., Salleh, F., and Muda, H (2017). Social Business Efficiency: Instrument Development and Validation Procedure using Structural Equation Modelling. International Business Management, 11(1), 222-231. 
INTERNATIONAL JOURNAL OF ACADEMIC RESEARCH IN BUSINESS AND SOCIAL SCIENCES

Vol. 10, No. 11, 2020, E-ISSN: 2222-6990 @ 2020 HRMARS

Hoque, A. S. M. M., Siddiqui, B. A., Awang, Z. B., \& Baharu, S. M. A. T. (2018). Exploratory Factor Analysis of Entrepreneurial Orientation in the Context of Bangladesh Small and Medium Entreprises (SMES). European Journal of Management and Marketing Studies.

Ji-fan Ren, S. (2017). Modelling quality dynamics on business value and firm performance in big data analytics environment. International Journal of Production Research.

Jaber, O. A. (2016). An Examination of Variables Influencing the Acceptance and Usage of E-Learning Systems in Jordanian Higher Education Institutions, 244.

Kanán, I. J. Y. (2017). The acceptance of e- learning as training tool from employees ' perspectives : The case of international management consulting organizations in State of Qatar Being a dissertation submitted in partial fulfilment of the requirements for the Degree of Maste.

Khwaldeh, S. M., Al-Hadid, I., Masa'deh, R., \& Alrowwad, A. (2017). The Association between EServices Web Portals Information Quality and ICT Competence in the Jordanian Universities. Asian Social Science, 13(3), 156. https://doi.org/10.5539/ass.v13n3p156

Koohang, A., \& Paliszkiewicz, J. (2016). E-Learning Courseware Usability: Building a Theoretical Model. Journal of Computer Information Systems, 56(1), 55-61. https://doi.org/10.1080/08874417.2015.11645801

Mahmoud, A. B., \& Khalifa, B. (2015). A Confirmatory Factor Analysis for SERVPERF Instrument based on a Sample of Students from Syrian Universities Education + Training Article information :, (March 2018). https://doi.org/10.1108/ET-04-2014-0038

Pham, L., Williamson, S., \& Berry, R. (2018). Student Perceptions of E-Learning Service, 14(3), $19-40$. https://doi.org/10.4018/IJEIS.2018070102

Noor, N. M., Aziz, A. A., Mostapa, M. R., \& Awang, Z. (2015). Validation of the Malay version of the Inventory of Functional Status after Childbirth questionnaire. BioMed research international, 2015.

Spielberger, C. D., Gorsuch, R. L., Lushene, R., Vagg, P. R., \& Jacobs, G. A. (1983). Manual for the statetrait anxiety scale. Consulting Psychologists

Sharma, S. K., \& Sharma, M. (2019). Examining the role of trust and quality dimensions in the actual usage of mobile banking services: An empirical investigation. International Journal of Information Management, 44(September 2018), 65-75.

https://doi.org/10.1016/j.ijinfomgt.2018.09.013

Yahaya, T., Idris, K., Suandi, T., \& Ismail, I. (2018). Adapting instruments and modifying statements: The confirmation method for the inventory and model for information sharing behavior using social media. Management Science Letters, 8(5), 271-282.

Zikmund, W. G. (2000). Business Research Methods, 6th (ed) Dryden Press. 